Article

\title{
Apis mellifera syriaca Venom: Evaluation of Its Anticoagulant Effect, Proteolytic Activity, and Cytotoxicity along with Its Two Main Compounds-MEL and PLA2-On HeLa Cancer Cells
}

\author{
Carole Yaacoub ${ }^{1,2,+}$, Rim Wehbe $^{3,+}\left(\mathbb{D}\right.$, Yahya Salma ${ }^{1,4}$, Dany El-Obeid ${ }^{5}$ (D), Romeo El Bersaoui ${ }^{4}$, Bruno Coutard ${ }^{2}$ \\ and Ziad Fajloun $1,4, *$ (D)
}

1 Laboratory of Applied Biotechnology (LBA3B), Azm Center for Research in Biotechnology and Its Applications, EDST, Lebanese University, Tripoli 1300, Lebanon; carole.yaacoub@etu.univ-amu.fr (C.Y.); yahya_salma@hotmail.com (Y.S.)

2 Unité des Virus Émergents, Aix-Marseille University-IRD 190-Inserm 1207, IHU Méditerranée Infection, 13005 Marseille, France; bruno.coutard@univ-amu.fr

3 Biology Department, Faculty of Arts and Sciences, American University of Beirut, Beirut 1107 2020, Lebanon; rimg.wehbe@gmail.com

4 Department of Biology, Faculty of Sciences 3, Lebanese University, Michel Slayman Tripoli Campus Ras Maska, Tripoli 1352, Lebanon; rbersawi@ul.edu.lb

5 Faculty of Agriculture and Veterinary Sciences, Lebanese University, Dekwaneh, Beirut 2832, Lebanon; dany.elobeid@ul.edu.lb

* Correspondence: ziad.fajloun@ul.edu.lb

+ These authors contributed equally to this work.

\section{check for}

updates

Citation: Yaacoub, C.; Wehbe, R.;

Salma, Y.; El-Obeid, D.; El Bersaoui,

R.; Coutard, B.; Fajloun, Z. Apis

mellifera syriaca Venom: Evaluation of Its Anticoagulant Effect, Proteolytic

Activity, and Cytotoxicity along with

Its Two Main Compounds-MEL and

PLA2-On HeLa Cancer Cells.

Molecules 2022, 27, 1653. https://

doi.org/10.3390/molecules27051653

Academic Editor: Weihong Lu

Received: 31 January 2022

Accepted: 28 February 2022

Published: 2 March 2022

Publisher's Note: MDPI stays neutral with regard to jurisdictional claims in published maps and institutional affiliations.

Copyright: (C) 2022 by the authors. Licensee MDPI, Basel, Switzerland. This article is an open access article distributed under the terms and conditions of the Creative Commons Attribution (CC BY) license (https:// creativecommons.org/licenses/by/ $4.0 /)$.

\begin{abstract}
Bee venom (BV) is one of the most remarkable natural products that has been a subject of studies since ancient times. Recent studies have shown that Apis mellifera syriaca venom possesses antibacterial as well as cytotoxic effects on cancer cell lines. The venom contains a variety of bioactive molecules-mainly melittin (MEL) and phospholipase A2 (PLA2), as well as other compounds that are not well characterized. In this work, we continue the biological characterization of $A$. mellifera syriaca venom by testing its anticoagulant effect on human plasma using the prothrombin time (PT) test, as well as assessing its proteolytic activity. In addition, the cytotoxicity of the crude venom-and of its two main components, MEL and PLA2-was tested on HeLa cancer cell lines for the first time. The results obtained showed the capacity of A. mellifera syriaca venom to increase clotting time, thereby proving its anticoagulant effect. Moreover, the venom did not demonstrate a significant proteolytic activity unless administrated at concentrations $\geq 5 \mathrm{mg} / \mathrm{mL}$. Finally, we showed that crude A. mellifera syriaca venom, along with MEL, exhibit a strong in vitro cytotoxic effect on HeLa cancer cell lines, even at low concentrations. In summary, our findings could serve as a basis for the development of new natural-based drug candidates in the therapeutic field.
\end{abstract}

Keywords: bee venom; Apis mellifera syriaca; anticoagulant effect; proteolytic activity; HeLa cell lines; melittin; PLA2

\section{Introduction}

Bees, one of the most remarkable social insects, are widespread, with more than 4000 species comprising both domestic and wild bees. Western honeybees (Apis mellifera) are eusocial insects found in Europe, Africa, North America, and the Middle Eastern region [1,2]; they are considered to be the primary pollinators of agricultural and horticultural crops [3].

Apis mellifera syriaca, also known as the "Syrian bee", is a subspecies of the Middle Eastern Apis mellifera bee (Lebanon, Syria, Jordan, Palestine, Iraq) [4]. This Middle Eastern insect presents several ecological characteristics, such as its adaptation to the hot and dry Mediterranean climate; it also presents a higher resistance to pests and pathogens than 
European bees, with more honey production, making it an interesting venomous insect to study [5].

Natural products are known to be a rich source of pharmaceutical molecules with minor side effects. Many studies have highlighted the importance of bee venom (BV), which has become one of the most examined natural products in recent years [6]. BV is a complex blend of bioactive molecules such as melittin (MEL), phospholipase A2 (PLA2), apamin, and hyaluronidase [7-9]. The use of BV for medicinal purposes-also known as apitherapy, or particularly bee venom therapy (BVT) — can be traced back thousands of years $[10,11]$. For example, BV has been used to treat diseases such as rheumatoid arthritis, neurodegenerative diseases, etc. Moreover, BV exerts an anticancer effect against several types of cancer cell lines by inducing apoptosis and necrosis [12-14].

MEL is the most abundant peptide in crude $A$. mellifera venom, corresponding to $40-60 \%$ of its composition; it exerts many biological activities, including antibacterial, antifungal, and anticancer activities $[15,16]$. It can disrupt the cell membrane by inserting itself across the phospholipid bilayer, leading to the formation of either transient or permanent pores [17]. Moreover, MEL is a lytic peptide that works by destabilizing the membranes of erythrocytes, resulting in hemolysis [18]. MEL is considered to be the most studied hymenopteran compound, as it possesses many therapeutic applications, including anticancer, anti-inflammatory and antiviral activities [19]. As a matter of fact, MEL was used in a phase II clinical trial study consisting of a group of patients suffering from chronic hepatitis B virus (HBV). The novel biotechnology, which is based on the RNA interference (RNAi) mechanism to induce efficient knockdown of target genes, employs MEL as an endosomolytic biopeptide in order to facilitate the delivery of short interfering RNA (siRNA) conjugates to the desired hepatocytes [20].

Bee venom-phospholipase A2 (Bv-PLA2), a hydrolytic enzyme, belongs to the group III sPLA2 enzymes [14]; it is considered to be the most toxic enzyme in BV, and accounts for $12-15 \%$ of the crude BV's dry weight [21]. Studies have shown that the activity of BVPLA2 can be induced by MEL during the erythrocyte lysis process as well as the cytotoxic activity against cancer cells, proving the existence of a synergistic action between the two biomolecules [22,23]. Furthermore, the synergistic action between MEL and Bv-PLA2 was also demonstrated in a recent study, where the combination of Bv-PLA2 with MEL improved the inhibition extent of membrane-bound Escherichia coli F1F0-ATPAse [15].

Thrombophilia, also known as hypercoagulable state, is when the blood tends to clot too much [24]. This can result in deep-vein thrombosis or arterial thrombosis, which can increase the risk of strokes, severe leg pain, heart attacks, and even amputations [25]. The number of people dying from thrombosis is increasing each year. At present, thrombosis is considered to be the among the leading causes of mortality-especially in the Western world [26].

Cancer-associated thrombosis-more specifically, venous thromboembolism (VTE)—is one of the most serious and most common causes of death in patients with malignancy [27]. Studies have shown that conventional cancer treatments, such as chemotherapy, can play a major role in increasing the risk of developing VTE in cancer patients in comparison to non-cancer patients [28]. Although many guidelines recommend the use of prophylactic low-molecular-weight heparin and direct oral anticoagulants for the treatment of cancerassociated VTE, their advantage is restricted by bleeding complications in cancer patients, mainly occurring at gastrointestinal sites [29,30]. As a result, the design of innovative anticancer drug candidates that also possess anticoagulant effects is highly relevant, and could imply the use of natural products.

In this context, and in order to improve the therapeutic value of the A. mellifera syriaca venom, we continue the biological characterization of this natural extract which previous studies demonstrated its capacity to inhibit the proliferation of antibiotic-resistant bacterial strains [4]. Moreover, it has been shown that $A$. mellifera syriaca venom possesses a strong dose-dependent blocking effect on Escherichia coli $\mathrm{F}_{1} \mathrm{~F}_{0}$-ATPase (with an $\mathrm{IC}_{50} \%$ higher than that obtained with the reference inhibitor of this enzyme) [15]. Furthermore, 
the venom has shown a considerable cytotoxic effect on different cancer cell lines, such as MCF-7 and HCT116 cell lines [4,23]. In this work, we evaluate for the first time the effects of $A$. mellifera syriaca venom on blood coagulation, as well as its proteolytic activity. Additionally, the cytotoxic effect of the crude venom was analyzed in parallel with its two main components-MEL and PLA2-on HeLa cancer cell lines.

\section{Results}

\subsection{Effect of A. mellifera syriaca Venom on Human Plasma Coagulation}

In order to evaluate the effect of $A$. mellifera syriaca venom on blood clotting, the prothrombin time (PT) test was performed. This test measures the activity of extrinsic coagulation factors-in particular, coagulation factor II, also known as prothrombin, which is a biological precursor of thrombin [31]. The results obtained reveal that A. mellifera syriaca venom shows an anticoagulant activity from a concentration as low as $50 \mu \mathrm{g} / \mathrm{mL}$ (Table 1, Figure 1). In fact, for a concentration of $50 \mu \mathrm{g} / \mathrm{mL}$, the time necessary for the blood to clot is $17.2 \mathrm{~s}$ with $68.7 \%$ plasma activity (see Section 4 ). The clotting time increases proportionally with the increase in the venom's concentration, reaching a maximum time of $62.3 \mathrm{~s}$ at a concentration of $5000 \mu \mathrm{g} / \mathrm{mL}$. In contrast, the activity of the plasma decreases with the increase in A. mellifera syriaca venom, achieving a minimum activity of $14.3 \%$ at a concentration of $5000 \mu \mathrm{g} / \mathrm{mL}$ (Table 1, Figure 1).

Table 1. PT test values for different $A$. mellifera syriaca venom concentrations.

\begin{tabular}{ccccc}
\hline $\begin{array}{c}\text { Apis mellifera syriaca } \\
\text { Venom Concentration } \\
\text { (mg/mL) }\end{array}$ & Time (s) & INR & Activity (\%) & Description \\
\hline Reference value & 13.3 & 1 & 100 & \\
Negative control & 13.3 & 1 & 100 & No clots were formed \\
Positive control & 90.1 & $>6$ & 14.3 & No clots were formed \\
5000 & 62.3 & 4.9 & 22 & Clots were formed as \\
3500 & 45.4 & 3.6 & 37 & small filaments \\
2000 & 27.2 & 2.1 & 38.3 & Idem \\
1000 & 26.3 & 2.1 & 40.6 & Idem \\
750 & 25.1 & 1.9 & 50 & Idem \\
500 & 21.3 & 1.6 & 65.3 & Clots were formed \\
250 & 17.5 & 1.3 & 64.7 & partially \\
200 & 17.8 & 1.3 & 67.3 & Idem \\
150 & 17.2 & 1.3 & 68.7 & Idem \\
50 & 17.2 & 1.3 & Idem \\
\hline
\end{tabular}

It is essential to note that the three parameters evaluated in this test are time (in seconds), which measures how long it takes for the blood to clot, and whose normal value is generally $13.3 \mathrm{~s}$; the activity (in \%) of the plasma, which in the normal case should be $100 \%$; and the INR (international normalized ratio), which represents the PT of the blood sample, and which in the normal case should be equivalent to 1 . For the positive control, heparin (33 USP units/mL blood) was used-a drug that acts as an anticoagulant, and whose administration has shown significantly low activity $(<10 \%)$ as well as a considerably high clotting time of $90 \mathrm{~s}$. 


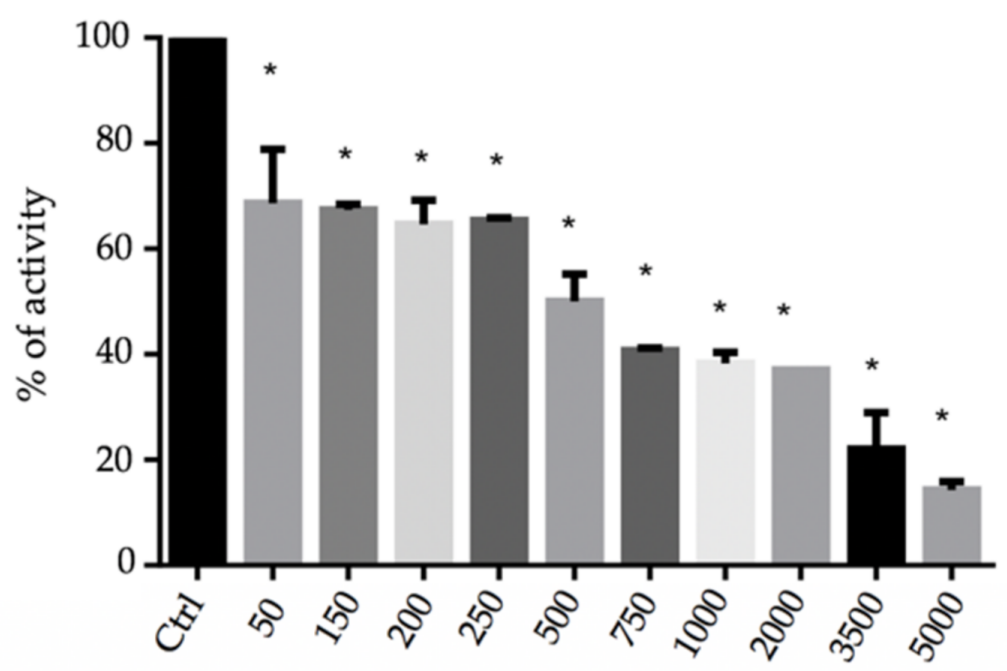

Apis mellifera syriaca venom concentration $(\mu \mathrm{g} / \mathrm{mL})$

Figure 1. Percentage of plasma activity as a function of the concentration of A. mellifera syriaca venom. The results represent the mean $\pm \mathrm{SD}$ of three independent experiments. Statistically compared with untreated cells; ${ }^{*} p<0.0001$.

Regarding the presence of blood clots in the human plasma tested, we first noticed their formation as fine filaments using a venom concentration of $1 \mathrm{mg} / \mathrm{mL}$. However, their presence became more evident for venom concentrations ranging from $50 \mu \mathrm{g} / \mathrm{mL}$ to up to $750 \mu \mathrm{g} / \mathrm{mL}$ (Table 1).

\subsection{Proteolytic Effect of A. mellifera syriaca Venom}

Honeybee venom is known to contain very few proteases [32] and peptidases [33]. Hence, in order to ensure that the proteolytic effect of the A. mellifera syriaca venom is not significant unless administrated at relatively high doses, the following proteolytic assay was performed. The skim milk agar plate method was originally used to assess the capacity of bacteria to degrade proteins. This capacity is due to the presence of proteases-enzymes that degrade proteins. The casein present in milk has a whitish, opaque appearance in the middle. If the sample possesses proteolytic activity, the enzymes will degrade the casein, leading to the loss of the white agar appearance around the deposits. The activity is therefore relative to the diameter of the area of clarification [34].

Four different concentrations of $A$. mellifera syriaca venom were used $(1,2.5,5$, and $10 \mathrm{mg} / \mathrm{mL}$ ), along with a pepsin solution used as a positive control. The results show that the proteolytic effect is only observed at considerable concentration of the venom (Figure 2A). Effectively, a minimum concentration of $5 \mathrm{mg} / \mathrm{mL}$ of the venom is needed in order to trigger the degradation of casein. This translates to the smallest thinning diameter, which is around 6 $\mathrm{mm}$. The activity slightly increases to reach $7 \mathrm{~mm}$ of diameter at a concentration of $10 \mathrm{mg} / \mathrm{mL}$ (Figure 2B). The slight proteolytic activity observed could be associated with the presence of a serine protease enzyme in the Apis mellifera venom [31]. The presence of this enzyme could enhance the distribution of the venom in the blood, leading to better circulation when used in vivo, without the intolerable consequence of protein digestion. 


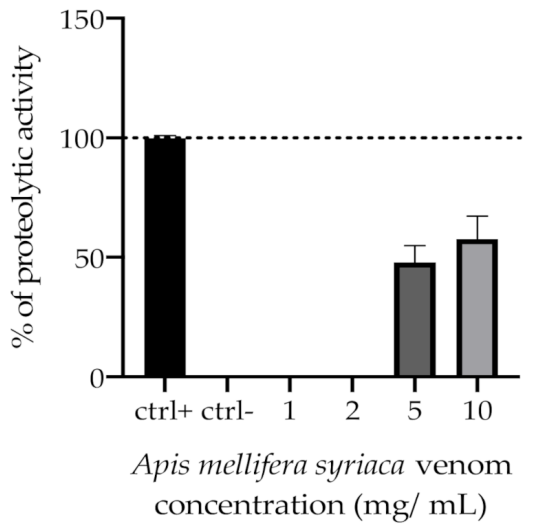

(A)

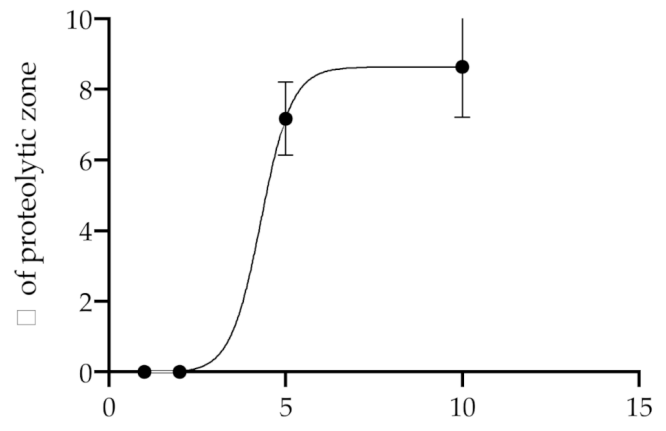

A. mellifera syriaca venom concentration $(\mathrm{mg} / \mathrm{mL})$

Figure 2. Proteolytic activity of $A$. mellifera syriaca venom, showing a dose-dependent effect at the concentrations being tested: (A) The proteolytic effect percentage of venom at the concentrations tested is presented in comparison with the positive control, inducing a percentage effect of $100 \%$ (positive control/pepsin), and the negative control, which has a percentage effect of $0 \%$ (negative control $/ \mathrm{H}_{2} \mathrm{O}$ ). (B) The dose-response curve of the venom is presented relative to the diameter of the proteolytic zone observed in the Petri dish, and corresponding to the degradation of casein by the A. mellifera syriaca venom. The results represent the mean $\pm \mathrm{SD}$ of three independent experiments.

\subsection{Cytotoxicity of A. mellifera syriaca Venom and of Its Two Main Components-MEL and PLA2-On HeLa Cancer Cell Lines}

After demonstrating the cytotoxic effect of $A$. mellifera syriaca venom on HCT116 cells in our previous work [23], we aimed to expand our research by testing the effect of the same venom on different cancer cell lines. Accordingly, four concentrations of $A$. mellifera syriaca venom were tested on HeLa cancer cells. The results were expressed as the percentage of cell viability in comparison to untreated control cells with $100 \%$ viability. The test used to calculate the percentage of cell viability was the MTT test. For a concentration of $0.5 \mu \mathrm{g} / \mathrm{mL}$, $81 \%$ of cells remained viable. This percentage significantly decreased with the increase in the venom concentration, reaching a minimum cell viability of $21 \%$ (Figure $3 \mathrm{~A}$ ). These results indicate the presence of a significant cytotoxic effect of $A$. mellifera syriaca venom on HeLa cells, with an $\mathrm{EC}_{50}$ of $3.9 \mu \mathrm{g} / \mathrm{mL}$ (Figure 3D).

Furthermore, cells were exposed to increasing concentrations of MEL $(1,2.5,5,10,25$, $50 \mu \mathrm{g} / \mathrm{mL}$ ) for $24 \mathrm{~h}$. The results obtained showed the presence of a strong cytotoxic effect of MEL against HeLa cancer cells. MEL inhibited the cell viability in a dose-dependent manner. A concentration of $5 \mu \mathrm{g} / \mathrm{mL}$ of MEL was able to induce a significant cytotoxic effect compared to untreated cells. The maximum cytotoxic effect was shown at a concentration of $50 \mu \mathrm{g} / \mathrm{mL}$, with only $17 \%$ viability (Figure $3 \mathrm{~B}$ ). The observed $\mathrm{EC}_{50}$ of MEL was $19.7 \mu \mathrm{g} / \mathrm{mL}$ (Figure $3 \mathrm{E}$ ).

Finally, six concentrations of Bv-PLA2 were tested $(0.25,0.5,1,2.5,5,10 \mu \mathrm{g} / \mathrm{mL})$. The results demonstrated that Bv-PLA2 alone does not exert any cytotoxic effect against HeLa cells, and no dose-dependent effect was observed (Figure $3 \mathrm{C}$ ).

Altogether, these findings confirm the cytotoxic effect of $A$. mellifera syriaca venom on HeLa cancer cells in vitro. Additionally, the results support the hypothesis of our previous work, which suggests the importance of MEL in conferring the BV's anticancer properties [23]. Moreover, by comparing the $\mathrm{EC}_{50}$ values of BV, MEL, and Bv-PLA2 with those of our previous work on human colon cancer cells [23], we found that MEL is more effective on human colon cancer cells $\left(\mathrm{EC}_{50}=14.05 \mu \mathrm{g} / \mathrm{mL}\right)$ than on HeLa cells $\left(\mathrm{EC}_{50}=19.7 \mu \mathrm{g} / \mathrm{mL}\right)$. In contrast, $\mathrm{BV}$ and Bv-PLA2 did not show a significant difference between the two types of cancer cells. This finding supports our first hypothesis regarding the mechanism of action of MEL against cancer cells not only by acting on different signaling pathways, but also by disturbing the cell membrane. However, this should be validated by further experimental studies. 
(A)

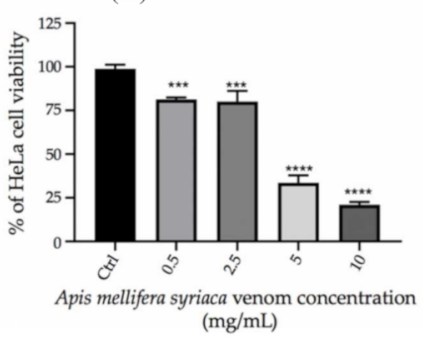

(D)

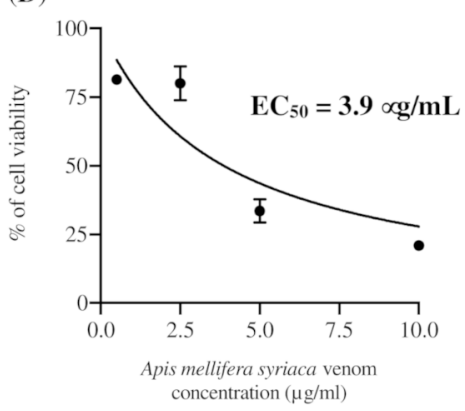

(B)

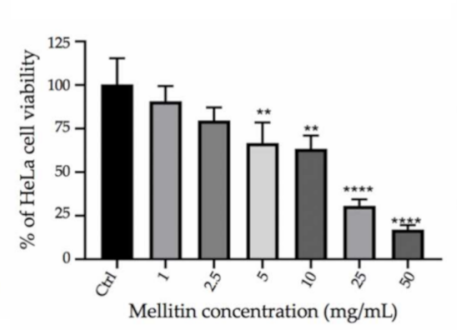

(C)

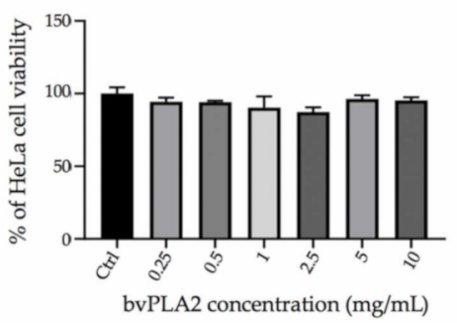

(E)

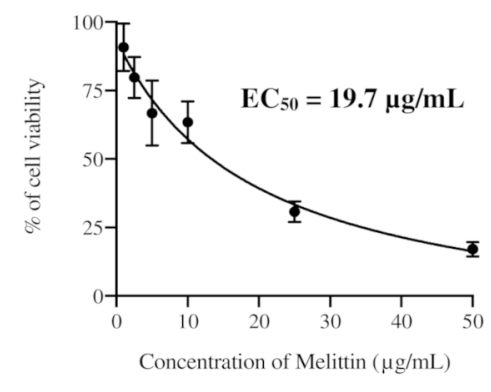

Figure 3. Cell viability of HeLa cancer cells, as measured by MTT test after treatment with increased concentrations of (A) A. mellifera syriaca venom, (B) MEL, and (C) Bv-PLA2. The results represent the mean \pm SD of three independent experiments. Statistically significant compared with untreated cells (control): ${ }^{* *} p<0.01,{ }^{* * *} p<0.001,{ }^{* * * *} p<0.0001$. (D) Curve for MTT assay showing the EC 50 value and $\%$ of cell viability as a function of $\log$ concentration of $A$. mellifera syriaca venom. The obtained $\mathrm{EC}_{50}$ of venom on HeLa cells was $3.9 \mu \mathrm{g} / \mathrm{mL}$. (E) Curve for MTT assay showing the $\mathrm{EC}_{50}$ value and $\%$ of cell viability as a function of $\log$ concentration of melittin. The obtained $\mathrm{EC}_{50}$ of melittin on HeLa cancer cells was $19.7 \mu \mathrm{g} / \mathrm{mL}$.

\section{Discussion}

In this work, we demonstrated the anticoagulant effect of $A$. mellifera syriaca venom using the prothrombin time (PT) test. In normal conditions, the activity of the plasma should range between $70 \%$ and $100 \%$ in order for the blood to clot. When this activity drops below $70 \%$, it indicates hypoprothrombinemia. Our results show that at a concentration of $50 \mu \mathrm{g} / \mathrm{mL}$, the A. mellifera syriaca venom was able to decrease the human plasma activity to $68 \%$, and in parallel to increase the clotting time to up to $17 \mathrm{~s}$, indicating the presence of an anticoagulant effect. Moreover, we found that the effect of the crude venom on blood coagulation is dose-dependent. In fact, for a concentration of $5000 \mu \mathrm{g} / \mathrm{mL}$ of $A$. mellifera syriaca venom, the plasma activity drastically decreased, reaching as low as $14 \%$; in contrast, the clotting time increased to $62 \mathrm{~s}$. Plasma diluted in ultrapure water was used as a negative control, since the venom is dissolved in water and the values obtained are the same as the reference value. For the positive control, heparin-a drug that acts as an anticoagulant-was used, and its administration showed a significantly low activity $(<10 \%)$ as well as a significantly high clotting time of $90 \mathrm{~s}$. In sum, these findings confirm the anticoagulant effect of $A$. mellifera syriaca venom. Previous work done by Accary et al. in 2014 studied the effect of Montivipera bornmuelleri snake venom on blood coagulation using the same PT test. The results demonstrated that from a concentration of $3 \mu \mathrm{g} / \mathrm{mL}$ the snake venom can act as an anticoagulant. The same study showed that the anticoagulant effect of the snake's venom is likely due to the presence of enzymes with anticoagulant activity, such as PLA2 [35]. Other studies have shown that $A$. mellifera venom from Iran contains anticoagulant factors that can increase the clotting time (prothrombin time), which is in total agreement with our findings [36]. Likewise, the same study demonstrated that MEL and PLA2 (which are also present in A. mellifera syriaca venom) are mainly responsible for 
this anticoagulant effect. This study supports another finding that showed that PLA2 from the venom of Egyptian honeybee Apis mellifera lamarckii exerts anticoagulant activities [37].

Moreover, it is known that the mechanism of coagulation involves activation, adhesion, and aggregation of platelets, along with deposition and maturation of fibrin [38]. A series of reactions are involved, in which inactive serine protease enzymes and their glycoproteins are activated, and can catalyze the next reaction in the cascade, leading to the coagulation of the blood [38]. Therefore, the mechanism of action of BV can be due to its effect on certain coagulation factors-such as inhibition of the serine protease enzymes-or it might have a direct effect on the platelets.

Proteases, and specifically serine proteases, play a major role in coagulopathies, and can act by driving the thrombotic and thrombolytic cascades [39]. A study conducted by Choo et al. in 2010 showed that serine protease from bumblebees' Bi-VSP acts as a prothrombin activator [32]. Given that the venom showed a significant anticoagulant effect, it is crucial to confirm that Apis mellifera syriaca venom-at the concentrations that demonstrated anticoagulant effects-does not possess a proteolytic activity that might contribute to the acceleration of blood coagulation, due the presence of its serine proteases. In this work, the proteolytic activity of $A$. mellifera syriaca venom was assessed in order to ensure that the effect is not significant unless the venom is administrated at concentrations $\geq 5 \mathrm{mg} / \mathrm{mL}$. The results obtained are in accordance with the literature, given that the proteases and peptidases present in the BV only represent a very small proportion of its total composition. Specifically, proteases and peptidases only constitute $1 \%$ of the BV's total weight [8]. This explains why the proteolytic effect of the A. mellifera syriaca venom was only present at concentrations $\geq 5 \mathrm{mg} / \mathrm{mL}$. Additionally, the crude BV contains serine protease inhibitors, which could also explain the absence of any proteolytic activity at moderate concentrations [40].

Finally, we demonstrated for the first time the cytotoxic effect of $A$. mellifera syriaca venom on HeLa cancer cell lines. The cytotoxic effect was significant even at low concentrations $(0.5 \mu \mathrm{g} / \mathrm{mL})$ of the crude venom. For a concentration of $5 \mu \mathrm{g} / \mathrm{mL}$, the proliferation of more than half of HeLa cells was inhibited. In addition, many studies have demonstrated that MEL-the main component of BV-is responsible for the cytotoxic effect of this extract $[38,41]$, which also explains why Bv-PLA2 alone did not show any cytotoxic effect on HeLa cancer cells in our work. Our findings correlate with those of Mansour et al. in 2021, whose in vitro data showed a dose-dependent antiproliferative activity of both BV and MEL on HepG2 cells, with the latter showing the highest cytotoxicity [42]. This is also consistent with our prior findings regarding $A$. mellifera syriaca venom, where MEL was proven to be the compound responsible for the cytotoxic effect on HCT116 human colon cancer cells-especially given its synergistic action with Bv-PLA2 [6].

In fact, the $\mathrm{EC}_{50}$ values obtained for the A. mellifera syriaca venom and MEL on HeLa cell lines correlate with those observed on HCT116 cells, where they were found to be equal to $3.14 \mu \mathrm{g} / \mathrm{mL}$ for the A. mellifera syriaca venom [6]. In contrast, MEL was more effective on HCT116 human colon cancer cells, with an $\mathrm{EC}_{50}=14.05 \mu \mathrm{g} / \mathrm{mL}$ [23], than on HeLa cells, with an $\mathrm{EC}_{50}=19.7 \mu \mathrm{g} / \mathrm{mL}$. Our results also correlate with previous studies that demonstrated the anticancer effects of BV against other types of cancer cells, such as lung cancer cells (with an $\mathrm{IC}_{50}=2 \mu \mathrm{g} / \mathrm{mL}$ ) [43] and ovarian cancer cells (with an $\mathrm{IC}_{50}=1.5 \mu \mathrm{g} / \mathrm{mL}$ ) [44]. However, MEL showed some variability in the $\mathrm{IC}_{50}$ values between different cancer cell types, and even between the cell strains of the same type of carcinoma. For example, the $\mathrm{IC}_{50}$ of MEL in ovarian cancer cells was equal to $3.8 \mu \mathrm{g} / \mathrm{mL}$ [44], whereas it was equal to $4.06 \mu \mathrm{g} / \mathrm{mL}$ and $9.24 \mu \mathrm{g} / \mathrm{mL}$ in MHCC97-H and MHCC97-L hepatocellular carcinomas, respectively. Interestingly, these two cell strains have different Rac1 expression levels, indicating that melittin's anti-HCC effect depends on Rac1 [45]. The main mechanism of action by which both BV and MEL act as anticancer agents is via inducing apoptosis in tumor cells. For example, MEL can trigger both extrinsic and intrinsic pathways, by increasing the expression levels of many proapoptotic and apoptotic mediators, such as cytochrome c, protein 53 (p53), Bcl-2-associated $X$ protein (Bax), caspase-3, caspase-9, and different types of death receptors $[11,12,46]$. In 
addition, it suppresses the growth factor receptor activation in breast cancer cell lines [41]. It has been also demonstrated that BV can increase the expression of DR3, which induces the apoptosis of lung cancer cells [43]. Moreover, it has been proven that MEL activates the death receptors and inhibits the JAK2L/STAT3 pathway, leading to the inhibition of ovarian cancer cell growth [44]; it can also decrease the expression levels of p-AKT and ERK1/2, and suppress the Rac1-dependent pathway [45].

Despite the wide range of therapeutic applications of both BV and MEL, their unwanted toxicity might limit their clinical development. Hence, many scientists aim to develop new approaches that decrease the toxicity of both BV and MEL. For example, it was demonstrated that loading BV on nanofungal chitosan increased its anti-cancer bioactivity against cervical carcinoma (HeLa) cells by inducing apoptosis in a time- and dose-dependent manner [47].

Finally, the synergistic action of both MEL and PLA2 has long been assessed via chemical processes, such as the hydrolysis of phospholipid monolayers [48,49]. As for the possible existence of a synergistic action between the BV's two main biomolecules in biological processes, we showed in our latest work that when MEL and Bv-PLA2 were combined together, a potential cytotoxic synergistic effect was observed, and translated into the significant inhibition of the HCT116 cells' proliferation. Hence, we speculate that a similar synergistic effect between MEL and Bv-PLA2 should also be present for HeLa cancer cells. The mechanism of action is probably the same as that reported by Mufson et al.-MEL enters the phospholipid bilayers and exhibits surfactant activity [50]. The association between MEL and the cellular membranes results in (1) a disturbance of the acyl groups of phospholipids, (2) increased phospholipid susceptibility to hydrolysis by PL, and (3) increased synthesis of PG from the arachidonic acid released from the phospholipids.

Altogether, our results support previous findings on the cytotoxic effects of BV and MEL on different types of cancer cells. Moreover, our study offers better insights on the specificity of MEL's mode of action against different types of cancer cells.

\section{Materials and Methods}

\subsection{Chemicals and Reagents}

First, $0.5 \mathrm{~g}$ of crude bee venom were collected from four beehives of healthy local beesA. mellifera syriaca (Lebanese subspecies) which are found in Matn in Mount Lebanon-by using the electroshock method Then, this venom was freeze-dried and stored at $-20^{\circ} \mathrm{C}$. The standard MEL and PLA2 were obtained from LATOXAN-a French laboratory specializing in animal toxins and poisonous animals.

\subsection{Cell Culture}

Human cervical cancer cells (HeLa) were obtained from the American Type Culture Collection (ATCC). Cells were cultured in Dulbecco's modified Eagle's medium (DMEM) supplemented with $10 \%$ heat-inactivated fetal bovine serum (FBS) and incubated at $37{ }^{\circ} \mathrm{C}$ in a humidified atmosphere with $5 \% \mathrm{CO}_{2}$.

\subsection{Prothrombin Time (PT) Test}

The effect of $A$. mellifera syriaca venom on blood coagulation was studied using the PT (prothrombin time) test [51]. The test was performed in a certified hematology laboratory, using the "STA Compact Max 2" hemostatic analyzer (Bruxelles, Belgium). Freshly collected blood from healthy volunteers who had not taken any medication for at least 2 weeks before sampling was collected in $3.2 \%$ sodium citrate tubes and used directly. The samples were centrifuged for $5 \mathrm{~min}$ at $4400 \mathrm{rpm}$, and the plasma was collected. Ten milligrams of $A$. mellifera syriaca venom initial solution was used to achieve the desired BV concentrations to be tested $(50,150,200,250,500,750,1000,2000,3500$, and $5000 \mu \mathrm{g} / \mathrm{mL})$. Then, $100 \mu \mathrm{L}$ of each concentrated BV solution was added to $1 \mathrm{~mL}$ of plasma solution. As for the negative control, $100 \mu \mathrm{L}$ of ultrapure water was added to $1 \mathrm{~mL}$ of plasma solution. For the positive control, $100 \mu \mathrm{L}$ of heparin solution was added to $1 \mathrm{~mL}$ of plasma solution. The PT test was 
performed on $1 \mathrm{~mL}$ of the plasma incubated with the neoplastic reagent for $1 \mathrm{~min}$ at room temperature. Coagulation was initiated by the addition of $0.025 \mathrm{M}$ calcium chloride $\mathrm{CaCl}_{2}$. The results were expressed as the time required for the formation of coagulation. The positive and negative controls were used to evaluate the results obtained in the presence of the venom.

\subsection{Proteolytic Effect}

The proteolytic activity of $A$. mellifera syriaca venom was evaluated on milk agar plates. Thus, $2.8 \mathrm{~g}$ of Mueller Hinton agar was dissolved in $100 \mathrm{~mL}$ of distilled water; the mixture was brought to a boil, and then autoclaved at $121^{\circ} \mathrm{C}$ for $20 \mathrm{~min}$. Next, the mixture was cooled, and $11 \mathrm{~mL}$ of skimmed and pasteurized milk was added aseptically when its temperature reached $45-50{ }^{\circ} \mathrm{C}$. The mixture was later poured into Petri dishes, which could be used once the medium solidifies. After solidification, $6 \mathrm{~mm}$ diameter wells were dug and loaded with $25 \mu \mathrm{L}$ of the solutions to be tested. The gearboxes were observed for the appearance of clear zones after incubation for $24 \mathrm{~h}$ at room temperature.

\subsection{Cytotoxic Activity Assay on HeLa Cancer Cells}

To investigate the venom's cytotoxicity, the MTT viability test was used [52]. Initial solutions of $1 \mathrm{mg} / \mathrm{mL}$ of $A$. mellifera syriaca crude venom, MEL, and PLA2 (Bv-PLA2) were prepared and filtered using a $0.2 \mu \mathrm{m}$ sterile syringe filter. Cells were cultured in DMEM culture medium until confluence. A 24-well plate was used. $1 \mathrm{~mL}$ of sample at the different concentrations was deposited in each well. Triplicate copies were made for the HeLa cells. This plate was incubated at $37^{\circ} \mathrm{C}$ for $24 \mathrm{~h}$. After incubation, a volume of $10 \mu \mathrm{L}$ of MTT was added to each well. This step was performed in the dark, as MTT is photosensitive. The plate was stirred and then incubated at $37^{\circ} \mathrm{C}$ for $1 \mathrm{~h}$. The medium was then removed, and 1 $\mathrm{mL}$ of DMSO was added to each well in order to solubilize formazan crystals. Absorbance quantification was read at $570 \mathrm{~nm}$.

\subsection{Statistical Analysis}

The results were obtained using one-way ANOVA with Bonferroni's multiple comparison test, using the GraphPad Prism software; they were presented as the mean $\pm \mathrm{SD}$ of at least three independent experiments. Statistical significance was defined as ${ }^{*} p<0.05,{ }^{* *} p<0.01$, and ${ }^{* * *} p<0.001$ compared to untreated cells.

\section{Conclusions}

In this work, we demonstrated that the venom obtained from A. mellifera syriaca bees (Lebanese subspecies) possesses an anticoagulant effect. In addition, we showed that the venom's proteolytic effect is insignificant unless administrated at high concentrations. Finally, we revealed the significant cytotoxic effect of $A$. mellifera syriaca venom as well as its main biopeptide (MEL) on HeLa cancer cells. Notably, we confirmed that Bv-PLA2 does not exert any cytotoxic activity when administrated alone. The biological proprieties of the venom of $A$. mellifera syriaca obtained in this work concerning, on the one hand, the presence of an anticoagulant effect on human plasma and a cytotoxic potential against HeLa cells, and on the other hand, the absence of a significant proteolytic activity, serve as a basis for the possible use of $A$. mellifera syriaca venom for the treatment of human diseases.

Author Contributions: Conceptualization, Z.F. and B.C.; methodology, C.Y., R.W., Y.S. and D.E.-O.; formal analysis, C.Y., R.W., R.E.B. and Z.F.; resources, B.C.; writing-original draft preparation, C.Y. and R.W.; writing-review and editing, R.E.B., B.C. and Z.F.; supervision, B.C. and Z.F.; project administration, Z.F. All authors have read and agreed to the published version of the manuscript.

Funding: This work was supported by the Lebanese University Research Funds.

Institutional Review Board Statement: The study was conducted according to the guidelines of the Declaration of Helsinki and approved by the Institutional Ethics Committee of Azm Center 
for Research in Biotechnology and its Applications, Doctoral School in Sciences and Biotechnology, Lebanese University (document no. CE-EDST-1-2022; date of approval, 2 February 2022).

Informed Consent Statement: Not applicable.

Data Availability Statement: Not applicable.

Acknowledgments: We would like to thank the "France Institute in Beirut/SAFAR program" for having awarded a doctoral study scholarship to C.Y. We also thank all of the research assistants of the LBA3B laboratory for their attribution on this work.

Conflicts of Interest: The authors declare no conflict of interest.

Sample Availability: Not applicable.

\section{References}

1. Cridland, J.M.; Tsutsui, N.D.; Ramírez, S.R. The Complex Demographic History and Evolutionary Origin of the Western Honey Bee, Apis Mellifera. Genome Biol. Evol. 2017, 9, 457-472. [CrossRef] [PubMed]

2. Han, F.; Wallberg, A.; Webster, M.T. From where did the Western honeybee (Apis mellifera) originate? Ecol. Evol. 2012, 2, 1949-1957. [CrossRef] [PubMed]

3. Applegate, J.R.; Petritz, O.A. Common and Emerging Infectious Diseases of Honeybees (Apis mellifera). Vet. Clin. N. Am. Exot. Anim. Pr. 2020, 23, 285-297. [CrossRef] [PubMed]

4. $\quad$ Frangieh, J.; Salma, Y.; Haddad, K.; Mattei, C.; Legros, C.; Fajloun, Z.; El Obeid, D. First Characterization of The Venom from Apis mellifera syriaca, A Honeybee from The Middle East Region. Toxins 2019, 11, 191. [CrossRef]

5. Zakour, M.K.; Ehrhardt, K.; Bienefeld, K. First estimate of genetic parameters for the Syrian honey bee Apis mellifera syriaca. Apidologie 2012, 43, 600-607. [CrossRef]

6. $\quad$ Zhang, S.; Liu, Y.; Ye, Y.; Wang, X.-R.; Lin, L.-T.; Xiao, L.-Y.; Zhou, P.; Shi, G.-X.; Liu, C.-Z. Bee venom therapy: Potential mechanisms and therapeutic applications. Toxicon 2018, 148, 64-73. [CrossRef]

7. Wehbe, R.; Frangieh, J.; Rima, M.; El Obeid, D.; Sabatier, J.-M.; Fajloun, Z. Bee Venom: Overview of Main Compounds and Bioactivities for Therapeutic Interests. Molecules 2019, 24, 2997. [CrossRef]

8. Abd El-Wahed, A.A.; Khalifa, S.A.M.; Sheikh, B.Y.; Farag, M.A.; Saeed, A.; Larik, F.A.; Koca-Caliskan, U.; AlAjmi, M.F.; Hassan, M.; Wahabi, H.A.; et al. Bee Venom Composition: From Chemistry to Biological Activity. Stud. Nat. Prod. Chem. 2018, 60, 459-484. [CrossRef]

9. Carpena, M.; Nuñez-Estevez, B.; Soria-Lopez, A.; Simal-Gandara, J. Bee Venom: An Updating Review of Its Bioactive Molecules and Its Health Applications. Nutrients 2020, 12, 3360. [CrossRef]

10. Nader, R.; Mackieh, R.; Wehbe, R.; El Obeid, D.; Sabatier, J.; Fajloun, Z. Beehive Products as Antibacterial Agents: A Review. Antibiotics 2021, 10, 717. [CrossRef]

11. Khalil, A.; Elesawy, B.H.; Ali, T.M.; Ahmed, O.M. Bee Venom: From Venom to Drug. Molecules 2021, 26, 4941. [CrossRef] [PubMed]

12. Oršolić, N. Bee venom in cancer therapy. Cancer Metastasis Rev. 2011, 31, 173-194. [CrossRef] [PubMed]

13. Jang, M.-H.; Shin, M.-C.; Lim, S.; Han, S.-M.; Park, H.-J.; Shin, I.; Lee, J.-S.; Kim, K.-A.; Kim, E.-H.; Kim, C.-J. Bee Venom Induces Apoptosis and Inhibits Expression of Cyclooxygenase-2 mRNA in Human Lung Cancer Cell Line NCI-H1299. J. Pharmacol. Sci. 2003, 91, 95-104. [CrossRef]

14. Bitar, L.; Jundi, D.; Rima, M.; Sabatier, J.-M.; Fajloun, Z. Bee Venom PLA2 Versus Snake Venom PLA2: Evaluation of Structural and Functional Properties. Venoms Toxins 2021, 1, 1-12. [CrossRef]

15. Nehme, H.; Ayde, H.; El Obeid, D.; Sabatier, J.-M.; Fajloun, F. Potential Inhibitory Effect of Apis mellifera's Venom and of Its Two Main Components-Melittin and PLA2-On Escherichia coli F1F0-ATPase. Antibiotics 2020, 11, 824. [CrossRef] [PubMed]

16. Memariani, H.; Memariani, M. Anti-fungal properties and mechanisms of melittin. Appl. Microbiol. Biotechnol. 2020, 104, 6513-6526. [CrossRef] [PubMed]

17. Chen, J.; Guan, S.-M.; Sun, W.; Fu, H. Melittin, the Major Pain-Producing Substance of Bee Venom. Neurosci. Bull. 2016, 32, 265-272. [CrossRef]

18. Raghuraman, H.; Chattopadhyay, A. Melittin: A Membrane-active Peptide with Diverse Functions. Biosci. Rep. 2007, 27, 189-223. [CrossRef]

19. Tiwari, R.; Tiwari, G.; Lahiri, A.; Ramachandran, V.; Rai, A. Melittin: A Natural Peptide with Expanded Therapeutic Applications. Nat. Prod. J. 2020, 10, 1. [CrossRef]

20. De Bordon, K.C.F.; Cologna, C.T.; Fornari-Baldo, E.C.; Pinheiro-Júnior, E.L.; Cerni, F.A.; Amorim, F.G.; Anjolette, F.A.P.; Cordeiro, F.A.; Wiezel, G.A.; Cardoso, I.A.; et al. From Animal Poisons and Venoms to Medicines: Achievements, Challenges and Perspectives in Drug Discovery. Front. Pharmacol. 2020, 11, 1132. [CrossRef]

21. Lee, G.; Bae, H. Bee Venom Phospholipase A2: Yesterday's Enemy Becomes Today's Friend. Toxins 2016, 8, 48. [CrossRef] [PubMed] 
22. Światły-Błaszkiewicz, A.; Mrówczyńska, L.; Matuszewska, E.; Lubawy, J.; Urbański, A.; Kokot, Z.J.; Rosiński, G.; Matysiak, J. The Effect of Bee Venom Peptides Melittin, Tertiapin, and Apamin on the Human Erythrocytes Ghosts: A Preliminary Study. Metabolites 2020, 10, 191. [CrossRef] [PubMed]

23. Yaacoub, C.; Rifi, M.; El-Obeid, D.; Mawlawi, H.; Sabatier, J.-M.; Coutard, B.; Fajloun, Z. The Cytotoxic Effect of Apis mellifera Venom with a Synergistic Potential of Its Two Main Components-Melittin and PLA2-On Colon Cancer HCT116 Cell Lines. Molecules 2021, 26, 2264. [CrossRef] [PubMed]

24. Dautaj, A.; Krasi, G.; Bushati, V.; Precone, V.; Gheza, M.; Fioretti, F.; Sartori, M.; Costantini, A.; Benedetti, S.M.B. Hereditary thrombophilia. Acta Biomed. 2019, 90, 44-46. [CrossRef] [PubMed]

25. Khalafallah, A.A.; Ibraheem, A.-R.O.; Teo, Q.Y.; Albarzan, A.-M.; Parameswaran, R.; Hooper, E.; Pavlov, T.; Dennis, A.E.; Hannan, T. Review of Management and Outcomes in Women with Thrombophilia Risk during Pregnancy at a Single Institution. ISRN Obstet. Gynecol. 2014, 2014, 381826. [CrossRef]

26. Majluf-Cruz, A. Trombophilia. Gac. Med. Mex. 2019, 153, 392-394. [CrossRef]

27. Razak, N.B.A.; Jones, G.; Bhandari, M.; Berndt, M.C.; Metharom, P. Cancer-Associated Thrombosis: An Overview of Mechanisms, Risk Factors, and Treatment. Cancers 2018, 10, 380. [CrossRef]

28. Short, N.J.; Connors, J.M. New Oral Anticoagulants and the Cancer Patient. Oncol. 2013, 19, 82-93. [CrossRef]

29. Agnelli, G.; Becattini, C.; Meyer, G.; Muñoz, A.; Huisman, M.V.; Connors, J.M.; Cohen, A.; Bauersachs, R.; Brenner, B.; Torbicki, A.; et al. Apixaban for the Treatment of Venous Thromboembolism Associated with Cancer. N. Engl. J. Med. 2020, 382, $1599-1607$. [CrossRef]

30. Xiong, W. Current status of treatment of cancer-associated venous thromboembolism. Thromb. J. 2021, 19, 1-12. [CrossRef]

31. Yang, R.; Moosavi, L. Prothrombin Time; StatPearls Publishing: Treasure Island, FL, USA, 2022; Bookshelf ID: NBK544269. Available online: https:/ / pubmed.ncbi.nlm.nih.gov/31334989/ (accessed on 30 January 2022).

32. Choo, Y.M.; Lee, K.S.; Yoon, H.J.; Kim, B.Y.; Sohn, M.R.; Roh, J.Y.; Je, Y.H.; Kim, N.J.; Kim, I.; Woo, S.D.; et al. Dual Function of a Bee Venom Serine Protease: Prophenoloxidase-Activating Factor in Arthropods and Fibrin(ogen)olytic Enzyme in Mammals. PLoS ONE 2010, 5, e10393. [CrossRef] [PubMed]

33. Hossen, M.S.; Shapla, U.M.; Gan, S.H.; Khalil, M.I. Impact of Bee Venom Enzymes on Diseases and Immune Responses. Molecules 2016, 22, 25. [CrossRef] [PubMed]

34. Głąb, T.K.; Boratyński, J. Potential of Casein as a Carrier for Biologically Active Agents. Top. Curr. Chem. (Cham) 2017, 375, 71 [CrossRef] [PubMed]

35. Accary, C.; Rima, M.; Kouzahya, A.; Hleihel, W.; Sadek, R.; Desfontis, J.C.; Fajloun, Z.; Hraoui-Bloquet, S.; Kouzayha, A. Effect of the Montivipera bornmuelleri snake venom on human blood: Coagulation disorders and hemolytic activities. Open J. Hematol. 2014, 5, 1-9. [CrossRef]

36. Zolfagharian, H.; Mohajeri, M.; Babaie, M. Honey Bee Venom (Apis mellifera) Contains Anticoagulation Factors and Increases the Blood-clotting Time. J. Pharmacopunct. 2015, 18, 7-11. [CrossRef]

37. Darwish, D.A.; Masoud, H.M.M.; Abdel-Monsef, M.M.; Helmy, M.S.; Zidan, H.A.; Ibrahim, M.A. Phospholipase A2 enzyme from the venom of Egyptian honey bee Apis mellifera lamarckii with anti-platelet aggregation and anti-coagulation activities. J. Genet. Eng. Biotechnol. 2021, 19, 1-8. [CrossRef]

38. Periayah, M.H.; Halim, A.S.; Mat Saad, A.Z. Mechanism Action of Platelets and Crucial Blood Coagulation Pathways in Hemostasis. Int. J. Hematol. Oncol. Stem Cell Res. 2017, 11, 319-327.

39. Drag, M.; Salvesen, G.S. Emerging principles in protease-based drug discovery. Nat. Rev. Drug Discov. 2010, 9, 690-701. [CrossRef]

40. De Lima, P.R.M.; Brochetto-Braga, M.R.; Chaud-Netto, J. Proteolytic activity of africanized honeybee (Apis mellifera: Hymenoptera, apidae) venom. J. Venom. Anim. Toxins 2000, 6, 64-67. [CrossRef]

41. Duffy, C.; Sorolla, A.; Wang, E.; Golden, E.; Woodward, E.; Davern, K.; Ho, D.; Johnstone, E.; Pfleger, K.; Redfern, A.; et al. Honeybee venom and melittin suppress growth factor receptor activation in HER2-enriched and triple-negative breast cancer. NPJ Precis. Oncol. 2020, 4, 1-16. [CrossRef]

42. Mansour, G.H.; El-Magd, M.A.; Mahfouz, D.H.; Abdelhamid, I.A.; Mohamed, M.F.; Ibrahim, N.S.; Wahab, A.H.A.A.; Elzayat, E.M. Bee venom and its active component Melittin synergistically potentiate the anticancer effect of Sorafenib against HepG2 cells. Bioorg. Chem. 2021, 116, 105329. [CrossRef] [PubMed]

43. Choi, K.E.; Hwang, C.J.; Gu, S.M.; Park, M.H.; Kim, J.H.; Park, J.H.; Ahn, Y.J.; Kim, J.Y.; Song, M.J.; Song, H.S.; et al. Cancer Cell Growth Inhibitory Effect of Bee Venom via Increase of Death Receptor 3 Expression and Inactivation of NF-kappa B in NSCLC Cells. Toxins 2014, 6, 2210-2228. [CrossRef] [PubMed]

44. Jo, M.; Park, M.H.; Kollipara, P.S.; An, B.J.; Song, H.S.; Han, S.B.; Kim, J.H.; Song, M.J.; Hong, J.T. Anti-cancer effect of bee venom toxin and melittin in ovarian cancer cells through induction of death receptors and inhibition of JAK2/STAT3 pathway. Toxicol. Appl. Pharmacol. 2012, 258, 72-81. [CrossRef] [PubMed]

45. Liu, S.; Yu, M.; He, Y.; Xiao, L.; Wang, F.; Song, C.; Sun, S.; Ling, C.; Xu, Z. Melittin prevents liver cancer cell metastasis through inhibition of the Rac1-dependent pathway. Hepatology 2008, 47, 1964-1973. [CrossRef]

46. Park, M.H.; Choi, M.S.; Kwak, D.H.; Oh, K.-W.; Yoon, D.Y.; Han, S.B.; Song, H.S.; Song, M.J.; Hong, J.T. Anti-cancer effect of bee venom in prostate cancer cells through activation of caspase pathway via inactivation of NF-KB. Prostate 2011, 71, 801-812. [CrossRef] 
47. Alalawy, A.I.; El Rabey, H.A.; Almutairi, F.M.; Tayel, A.A.; Al-Duais, M.A.; Zidan, N.S.; Sakran, M.I. Effectual Anticancer Potentiality of Loaded Bee Venom onto Fungal Chitosan Nanoparticles. Int. J. Polym. Sci. 2020, 2020, 2785304. [CrossRef]

48. Grandbois, M.; Dufourcq, J.; Salesse, C. Study of the synergistic action of phospholipase A2 and melittin in the hydrolysis of phospholipid monolayers. Thin Solid Films 1996, 284-285, 743-747. [CrossRef]

49. Damianoglou, A.; Rodger, A.; Pridmore, C.; Dafforn, T.R.; Mosely, J.A.; Sanders, J.M.; Hicks, M.R. The Synergistic Action of Melittin and Phospholipase A2 with Lipid Membranes: Development of Linear Dichroism for Mem-brane-Insertion Kinetics. Protein Pept. Lett. 2010, 17, 1351-1362. [CrossRef]

50. Mufson, R.A.; Laskin, J.D.; Fisher, P.B.; Weinstein, I.B. Melittin shares certain cellular effects with phorbol ester tumour promoters. Nature 1979, 280, 72-74. [CrossRef]

51. Tripathi, M.M.; Egawa, S.; Wirth, A.G.; Tshikudi, D.M.; Van Cott, E.M.; Nadkarni, S.K. Clinical evaluation of whole blood prothrombin time (PT) and international normalized ratio (INR) using a Laser Speckle Rheology sensor. Sci. Rep. 2017, 7, 9169. [CrossRef]

52. Kuete, V.; Karaosmanoğlu, O.; Sivas, H. Anticancer Activities of African Medicinal Spices and Vegetables. In Medicinal spices and vegetables from Africa; Academic Press: Cambridge, MA, USA, 2017; pp. 271-297. [CrossRef] 